\title{
ANALISIS IMPLEMENTASI PAJAK PERTAMBAHAN NILAI (PPN) PADA INDUSTRI KUE NAK MBAREP KEPATIHAN
}

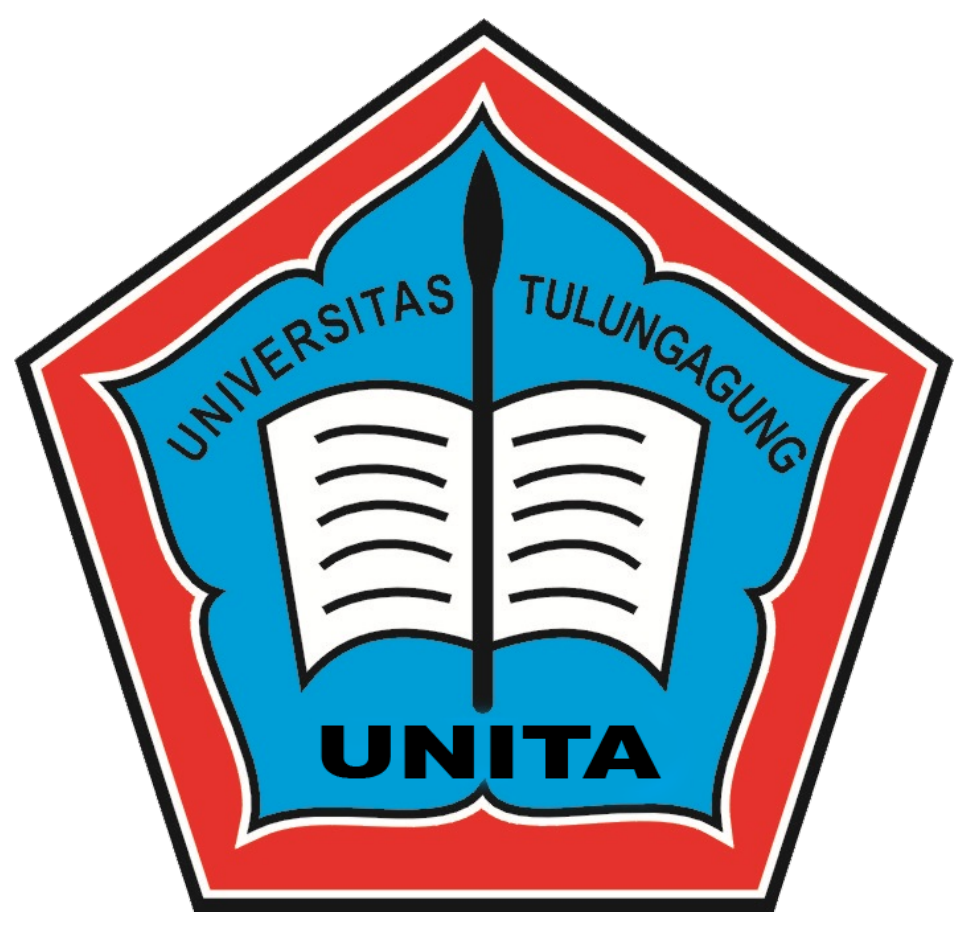

Oleh :

Novita Anjarsari 1960301100011

Risky Nurfadila 1960301100013

Iswatul Saldina 1960301100023

PROGRAM STUDY AKUNTANSI

FAKULTAS EKONOMI

UNIVERSITAS TULUNGAGUNG

TAHUN AKADEMIK 2020/2021 


\section{Abstract:}

This study is intended to determine the calculation of Value Added Tax (VAT) which is used in the cake industry of the Kepatihan nak mbarep cake. VAT is a type of tax that is used to analyze and calculate the value added value contained in an item. From the data obtained from the Nak Mbarep Kepatihan home cake industry, we as the authors of this study conducted an analysis on the calculation of the Value Added Tax (VAT) used by the Nak Mbarep Cake Industry whether it is in accordance with the new Taxation Law.

The research method used is primary data with data analysis techniques through interviews. The results of our research show that the home-based cake industry, nak mbarep, is still not in accordance with the amendments to the new taxation law, so the profit is less because the tax rate is too large.

Keywords : VAT, tax rates, tax laws.

\section{Abstrak:}

Penelitian ini dimaksudkan untuk mengetahui perhitungan Pajak Pertambahan Nilai (PPN) yang di digunakan pada toko kue nak mbarep kepatihan. PPN ialah salah satu jenis pajak yang digunakan untuk menganalisis serta menghitung besar pertambahan nilai yang terkandung dalam suatu barang. Dari data yang diperoleh dari industri kue rumahan nak mbarep kepatihan, kami selaku penulis dari penelitian ini melakukan analisis pada perhitungan Pajak Pertambahan Nilai (PPN) yang dipakai toko kue nak mbarep apakah sudah sesuai dengan Undang-Undang Perpajakan yang baru.

Metode penelitian yang digunakan merupakan data primer dengan teknik analisis data melalui interview. Hasil dari penelitian yang kami dapat bahwa toko kue rumahan nak mbarep masih belum sesuai dengan perubahan Undang-Undang Perpajakan yang baru, sehingga laba yang diperoleh lebih sedikit karena tarif pajak terlalu besar.

Kata kunci: PPN, Tarif pajak, Undang-undang perpajakan. 


\section{PENDAHULUAN}

Pemerintah telah mengadakan beberapa perubahan terhadap peraturan perpajakan yang lama berupa Undang-Undang Nomor 8 Tahun 1983 menjadi Undang-Undang Nomor 18 Tahun 2000, tentang Pajak Pertambahan Nilai Barang dan Jasa Penjualan atas Barang Mewah. Undang-Undang Pajak Pertambahan Nilai 1984 menganut metode kredit pajak serta metode faktur pajak. Dalam metode ini Pajak Pertambahan Nilai (PPN) dikenakan atas penyerahan Barang Kena Pajak (BKP) atau Jasa Kena Pajak (JKP) oleh Pengusaha Kena Pajak (PKP). Unsur pengenaan pajak atas pajak dapat dihindari dengan diterapkannya mekanisme pengkreditan pajak masukan (metode kredit pajak). Untuk melakukan pengkreditan pajak masukan, sarana yang digunakan adalah faktur pajak (metode faktur pajak). Semua biaya yang berkaitan dengan menghasilkan, menyalurkan dan memperdagangkan atau dalam memberikan pelayanan jasa merupakan unsur pertambahan nilai yang menjadi dasar pengenaan Pajak Pertambahan Nilai (PPN). Jadi dapat disimpulkan bahwa Pajak Pertambahan Nilai (PPN) adalah pajak yang dikenakan atas pertambahan nilai dari barang kena pajak atau jasa kena pajak.

Toko kue nak mbarep kepatihan adalah perusahaan yang beroperasi dibidang makanan. Karena mendapatkan keuntungan dari penjualan makanan tersebut maka Toko kue nak mbarep kepatihan dikenakan biaya pajak, dalam perhitungan pajak pertambahan nilainya dengan cara penjualan setiap produk dikalikan tarif pajak pertambahan nilai sebesar $10 \%$ jadi, jumlah tersebut adalah yang menjadi pajak pertambahan nilai dari toko kue nak mbarep kepatihan.

Dengan dikeluarkannya pajak akan dapat membantu meringankan biaya pembangunan dan dapat mensejahterakan rakyat Indonesia. Dengan adanya pajak tersebut maka dapat simpulkan bahwa semua yang menghasilkan keuntungan akan dikenakan pajak. Penerimaan pajak merupakan salah satu sumber pembiayaan pembangunan nasional yang cukup dominan. Perubahan struktur ekonomi dari ekonomi agraris ke ekonomi industri mengakibatkan semakin meningkatnya peran pajak, khususnya Pajak Pertambahan Nilai (PPN), terhadap pembiayaan pembangunan nasional. Menyadari akan hal ini, penggalian dan usaha peningkatan penerimaan pajak terus diupayakan. 


\section{RUMUSAN MASALAH}

1. Bagaimana penerapan akuntansi Pajak Pertambahan Nilai (PPN) pada Toko Kue Nak Mbarep Kepatihan?

2. Apakah perhitungan, penyetoran dan pelaporan Pajak Pertambahan Nilai (PPN) pada Toko Kue Nak Mbarep Kepatihan sudah sesuai dengan peraturan yang berlaku?

\section{LANDASAN TEORI}

\section{Pengertian Pajak}

Mardiasmo (2003:10), “Pajak adalah iuran wajib, berupa uang atau barang, yang dipungut oleh penguasa berdasarkan norma-norma hukum, guna menutup biaya produksi barang-barang dan jasa-jasa dalam mencapai kesejahteraan umum".

Menurut Mardiasmo (2003:11), “ Pajak adalah iuran rakyat pada kas negara berdasarkan Undang-undang (yang dapat dipaksakan) dengan tidak mendapatkan jasa imbalan, yang langsung dapat ditunjukkan dan yang digunakan untuk pengeluaran umum".

Menurut Waluyo (2002:4), "Pajak adalah iuran kepada Negara (yang dapat dipaksakan) yang terutang oleh yang wajib membayarnya menurut peraturanperaturan, dengan tidak mendapat prestasi kembali yang langsung dapat ditunjuk, dan yang gunanya adalah untuk membiayai pengeluaran-pengeluaran umum berhubungan dengan tugas Negara yang menyelenggarakan pemerintah".

Menurut Helmy (2005:7), “Pajak adalah prestasi pemerintah yang terutang melalui norma-norma umum dan yang dapat dipaksakan, tanpa adanya kontra prestasi yang dapat ditunjukkan dalam hal yang individual, maksudnya adalah membiayai pengeluaran pemerintah".

Menurut Hidayah (2008:65), “ Pajak ialah iuran yang harus dibayar oleh wajib pajak (masyarakat) kepada Negara (pemerintah) berdasarkan undang-undang dan tidak memperoleh balas jasa secara langsung. 


\section{Ciri-ciri Pajak}

a. Pajak peralihan kekayaan dari orang atau badan ke pemerintah.

b. Pajak dipungut dengan kekuatan Undang-undang serta aturan pelaksanaannya, sehingga dapat dipaksakan.

c. Pajak digunakan untuk kepentingan umum.

d. Dalam pembayaran pajak tidak dapat ditunjukkan adanya kontreprestasi langsung secara individual kepada pemerintah.

e. Pajak dipungut oleh Negara baik oleh pemerintah pusat maupun pemerintah daerah.

f. Pajak diperuntukkan bagi pengeluaran-pengeluaran pemerintah, yang bila dari pemasukkannya masih terdapat surplus, maka dipergunakan untuk membiayai investasi publik.

\section{Fungsi Pajak}

a. Fungsi budgetair, yaitu pajak-pajak disini merupakan suatu alat atau sumber untuk memasukkan uang sebanyak-banyaknya ke kas Negara yang pada waktunya akan digunakan untuk membiayai pengeluaran-pengeluaran rutin apabila setelah itu ada sisa, maka surplus ini dapat digunakan untuk membiayai investasi pemerintah

b. Fungsi mengatur, yaitu bahwa pajak-pajak dalam hal ini digunakan sebagai alat untuk mencapai tujuan-tujuan tertentu yang letaknya di luar bidang keuangan.

\section{Pengertian Pajak Pertambahan Nilai}

Pajak Pertambahan Nilai (PPN) adalah pajak yang dapat dikenakan terhadap penyerahan atau impor barang kena pajak atau jasa kena pajak yang dilakukan oleh pengusaha kena pajak dan dapat dikenakan berkali-kali setiap ada Pajak Pertambahan Nilai (PPN) dan dikreditkan Suandy (2003:59).

Dengan demikian pertambahan nilai itu sendiri timbul karena digunakannya faktor- faktor produksi pada setiap jalur perusahaan dalam menghasilkan, menyalurkan dan memperdagangkan barang atau dalam memberikan pelayanan jasa. Semua biaya yang berkaitan dengan menghasilkan, menyalurkan dan memperdagangkan atau dalam memberikan pelayanan jasa merupakan unsur 
pertambahan nilai yang menjadi dasar pengenaan Pajak Pertambahan Nila(PPN). Jadi dapat disimpulkan bahwa Pajak Pertambahan Nilai (PPN) adalah pajak yang dikenakan atas pertambahan nilai dari barang kena pajak atau jasa kena pajak.

\section{Subyek Pajak Pertambahan Nilai}

Subyek pajak adalah mereka yang menjadi penanggung jawab atas hutang pajak yang bertanggung jawab atas penyetoran pajak ke kas Negara berdasarkan Undangundang No. 18 Tahun 2000 adalah :

Dalam Peraturan Perpajakan No. 18 Tahun 2000 mengenai Pajak Pertambahan Nilai banyak istilah atau pengertian-pengertian penting yang perlu diketahui dalam Pajak Pertambahan Nilai (PPN) antara lain :

- Pengusaha adalah orang pribadi atau badan dalam bentuk apa pun yang dalam lingkungan perusahaan atau pekerjaannya menghasilkan barang, mengimpor barang, mengekspor barang, melakukan usaha dagang, memanfaatkan barang tidak berwujud dari luar pabean, melakukan usaha jasa dari luar daerah pabean.

- Pengusaha Kena Pajak (PKP) adalah orang atau badan dalam bentuk apapun yang dalam lingkungan pekerjaannya atau perusahaannya menghasilkan barang, mengimpor barang, mengekspor barang, melakukan usaha perdagangan atau melakukan usaha jasa yang dikenakan Pajak Pertambahan Nilai.

- Badan adalah sekumpulan orang atau modal yang merupakan kesatuan baik yang melakukan usaha maupun yang tidak melakukan usaha yang meliputi perseroan terbatas, perseroan komanditer, perseroan lainnya, badan usaha milik Negara atau daerah dengan nama dan dalam bentuk apa pun, firma kongsi, koperasi, dana pensiun, persekutuan, perkumpulan, yayasan, organisasi massa, organisasi social politik, atau organisasi yang sejenis, lembaga, bentuk usaha tetap, dan bentuk badan lainnya.

- Barang Kena Pajak (BKP) adalah barang berwujud yang menurut sifat atau hukuman dapat berupa barang bergerak maupun barang tidak bergerak sebagai hasil proses pengolahan (pabrikasi) yang dikenakan pajak 
berdasarkan undang-undang.

- Jasa adalah setiap kegiatan pelayanan berdasarkan suatu perikatan atau perbuatan hukum yang menyebabkan suatu barang atau fasilitas atau kemudahan atau hak tersedia untuk dipakai termasuk jasa yang dilakukan untuk menghasilkan barang karena pesanan atau permintaan dengan bahan dan atas petunjuk dari pemesan.

- Jasa Kena Pajak (JKP) adalah semua kegiatan usaha dan pemberian pelayanan berdasarkan suatu peringkatan atau perbuatan hukum yang menyebabkan suatu barang, fasilitas atau hak tersedia untuk dipakai, yang dikenakan Pajak Pertambahan Nilai.

- Penyerahan Jasa Kena Pajak adalah setiap kegiatan pemberian Jasa Kena Pajak sebagaimana dimaksud pada huruf d, termasuk Jasa Kena Pajak yang digunakan untuk kepentingan sendiri atau Jasa kena Pajak yang diberikan secara cuma-cuma oleh Pengusaha Kena Pajak.

- Daerah pabean adalah wilayah negara RI yang didalamnya berlaku peraturan perundangundangan Pabean.

- Masa Pajak adalah jangka waktu yang lamanya sama dengan satu bulan takwin kecuali ditetapkan lain oleh Menteri Keuangan.

- Tahun Pajak adalah jangka waktu 1 (satu) tahun takwim kecuali bila Wajib Pajak menggunakan tahun buku yang tidak sama dengan tahun takwim. Jika Wajib Pajak menggunakan tahun buku tidak sama dengan tahun takwim maka tahun pajak adalah tahun dimana lebih dari enam bulan ada di dalamnya.

- Bagian Tahun Pajak adalah bagian dari jangka waktu 1 (satu) tahun pajak.

- Pajak yang Terutang adalah pajak yang harus dibayar pada suatu saat, dalam Masa Pajak, dalam Tahun Pajak ada dalam Bagian Tahun Pajak menurut ketentuan peraturan perundang-undangan perpajakan.

- Faktur Pajak adalah bukti pemungutan pajak yang dibuat oleh Pengusaha Kena Pajak (PKP) atau Direktoral Jendral Bea Cukai pada saat penyerahan Barang Kena Pajak (BKP) atau impor Barang Kena Pajak (BKP).

- Pajak Masukan adalah Pajak Pertambahan Nilai (PPN) yang dibayar oleh Pengusaha Kena Pajak (PKP) pada waktu pembelian Barang Kena Pajak (BKP) penerimaan Jasa Kena Pajak (JKP) atau impor Barang Kena Pajak (BKP).

- Pajak Keluaran adalah Pajak Pertambahan Nilai (PPN) yang dipungut oleh 
Pengusaha Kena Pajak (PKP) pada waktu penyerahan Barang Kena Pajak (BKP) atau Jasa Kena Pajak (JKP).

- Kredit Pajak untuk Pajak Pertambahan Nilai adalah pajak masukan yang dapat dikreditkan setelah dikurangi dengan pajak yang telah dikompensasikan, yang dikurangkan dari pajak yang terutang.

Pengusaha yang menurut Undang-undang harus dikukuhkan menjadi Pengusaha Kena Pajak (PKP) pengusaha atau wajib pajak yang otomatis adalah:

1) Pabrikan atau produsen termasuk pengusaha real estate/ industrial estate/ developer atau pengusaha yang menghasilkan barang kena pajak.

2) Pengusaha yang mengimpor barang kena pajak.

3) Pengusaha yang mempunyai hubungan istimewa dengan pabrikan atau importer.

4) Agen utama dan penyaluran utama dari pabrikan atau importer.

5) Pemegang hak patent dan merk dagang dari barang kena pajak.

6) Pemborong/ kontraktor/ subkontraktor bangunan dan harta tetap lainnya

7) Pengusaha yang tidak termasuk ruang lingkup pengenaan pajak akan tetapi menyatakan memilih untuk dikukuhkan menjadi Pengusaha Kena Pajak (PKP) ialah :

a. Eksportir

b. Pedagang yang menjual Barang Kena Pajak (BKP).

Obyek Pajak Pertambahan Nilai

Menurut Helmy (2005:63) Obyek Pajak Pertambahan Nilai dikenakan berikut :

1) Penyerahan Barang Kena Pajak di dalam daerah pabean yang dilakukan pengusaha.

2) Penyerahan barang yang dikenakan pajak harus memenuhi syarat - syarat sebagai berikut :

a. Barang berwujud yang diserahkan merupakan Barang Kena Pajak,

b. Barang tidak berwujud yang diserahkan merupakan Barang Kena Pajak 
tidak berwujud,

c. Penyerahan dilakukan di dalam daerah pabean, dan

d. Penyerahan dilakukan dalam rangka kegiatan usaha atau kegiatan.

Tarif Pajak Pertambahan Nilai menurut ketentuan Undang-undang RI Tahun 2000 pasal 7 adalah :

a. Tarif Pajak Pertambahan Nilai adalah $10 \%$.

b. Tarif Pajak Pertambahan Nilai atas ekspor barang kena pajak adalah 0\% (nol persen).

c. Dengan peraturan pemerintah tarif pajak dapat diubah serendah-rendahnya $5 \%$ (lima persen) dan setinggi-tingginya $15 \%$.

d. Pajak Pertambahan Nilai untuk pabrikan yaitu 10\% untuk perhitungan pajak keluarannya.

\section{Perhitungan Pajak Pertambahan Nilai}

Besarnya Pajak Pertambahan Nilai (PPN) dapat dihitung dengan selisih antara pajak yang telah dipungut pada saat penjualan atau penyerahan suatu barang atau jasa kena pajak. Penerimaan jasa kena pajak atau import barang kena pajak (pajak masukan). Apabila dalam suatu masa pajak, pajak keluaran lebih besar dari pada pajak masukkan, maka selisihnya merupakan Pajak Pertambahan Nilai (PPN) yang harus dibayar oleh Pengusaha Kena Pajak. Apabila dalam suatu masa pajak, pajak masukkan yang dapat dikreditkan lebih besar dari pajak keluaran, maka selisihnya merupakan kelebihan pajak yang dapat dikompensasikan pada masa pajak berikutnya.

\section{Mekanisme Pemungutan PPN}

Mekanisme pemungutan PPN sesuai dengan PMK Nomor 85/PMK.03/2012 tanggal 06 Juni 2012 yang berlaku efektif mulai 1 Juli 2012 adalah:

a. Mekanisme pemungutan PPN yang pertama dan wajib adalah rekanan 
wajib membuat faktur pajak dan surat setoran pajak (SSP) atas setiap penyerahan BKP dan/atau JKP kepada BUMN.

b. Mekanisme pemungutan PPN yang kedua adalah faktur pajak sebagaimana dimaksud pada angka 1 dibuat sesuai dengan ketentuan di bidang perpajakan.

c. Ketiga adalah SSP sebagaimana dimaksud pada angka 1 diisi dengan membubuhkan NPWP serta identitas rekanan, tetapi penandatanganan SSP dilakukan oleh BUMN sebagai penyetor atas nama rekanan.

d. Keempat adalah dalam hal penyerahan BKP selain terutang PPN juga terutang PPnBM maka rekanan harus mencantumkan juga jumlah PPnBM yang terutang pada faktur pajak.

e. Kelima adalah faktur pajak dibuat dalam rangkap 3 dengan peruntukkan sebagai berikut : lembar kesatu untuk BUMN, lembar kedua untuk rekanan, dan lembar ketiga untuk BUMN yang dilampirkan pada SPT

f. Keenam adalah SSP sebagaimana dimaksud pada angka 1 dibuat dalam rangkap 5 dengan peruntukkan sebagai berikut : lembar kesatu untuk rekanan, lembar kedua untuk KPPN melalui Bank Persepsi atau Kantor Pos, lembar ketiga untuk rekanan yang dilampirkan pada SPT Masa PPN, lembar keempat untuk Bank Persepsi atau Kantor Pos, dan lembar kelima untuk BUMN yang dilampirkan pada SPT Masa PPN bagi Pemungut PPN.

g. Mekanisme Pemungutan PPN yang terakhir adalah faktur Pajak dan SSP merupakan bukti pemungutan dan penyetoran PPN atau PPN dan PPnBM

2. Mekanisme pelaporan PPN 
Pelaporan dilakukan setiap bulan dan laporan disampaikan ke KPP tempat BUMN terdaftar paling lama akhir bulan berikutnya setelah berakhirnya masa pajak dengan menggunakan formulir "Surat Pemberitahuan Masa PPN bagi Pemungut PPN" dan dilampiri dengan faktur pajak lembar ke-3 dan Surat Setoran Pajak (SSP) lembar ke-5 dalam hal terdapat pemungutan Pajak Pertambahan Nilai atau Pajak Pertambahan Nilai dan Pajak Penjualan atas Barang Mewah (Prabowo 2019)

\section{METODE PENELITIAN}

\section{Gambar 1}

Kerangka Konseptual

\section{Perhitungan Pajak \\ Pertambahan Nilai yang diterapkan di nerusahaan}

Perhitungan Pajak Pertambahan Nilai berdasarkan Undangundang perpajakan

\section{Keterangan :}

Pada penelitian ini, peneliti melakukan perbandingan antara Perhitungan Pajak Pertambahan Nilai (PPN) yang diterapkan di dalam perusahaan terhadap kajian teoritis yang terdapat pada undang-undang Perpajakan Indonesia yang dikeluarkan oleh pemerintah. Studi perbandingan yang dimaksud adalah dalam 
bentuk analisis kuantitatif deskriptif.

Jenis Penelitian

Dalam penelitian ini penulis menggunakan metode deskriptif kualitatif. Data kualitatif merupakan informasi dalam bentuk kalimat bukan berupa angka maupun symbol. Dengan menggunakan penelitian kualitatif, peneliti dapat mengetahui subyek dan mengetahui keadaan yang dialami mereka dalam kehidupan sehari-hari. Penelitian kualitatif juga menghasilakn data deskriptif. Data deskriptif merupakan data yang rinci, menjelaskan suatu masalah dengan jelas sampai ke akarnya, dan menjelaskan suatu fenomena secara detail. Metode ini bertujuan untuk mengetahui gambaran jelas menganai masalah dengan utuh dan sesuai fakta sesuai gambaran manusia yang melakukan penelitian.

Subyek Penelitian

Subyek penelitian ini adalah Industri Kue Nak Mbarep di Kepatihan Tulungagung. Sarana Teknik sedangkan yang menjadi obyek pada penelitian ini yaitu data mengenai perhitungan Pajak Pertambahan Nilai (PPN) dan laporan laba rugi perusahaan.

\section{Teknik Analisa Data}

1. Reduksi Data;

Reduksi data merupakan pemsuatan perhatian, proses pemilihan pada pengabstrakan, penyederhanaan dan transformasi data yang kasar yang muncul dari catatan dilapangan

2. Penyajian Data;

Penyajian data ini tersusun berbagai informasi yang bisa terjadi pengambilan keputusan dan penarikan kesimpulan. Setelah itu penyajian data digunakan agar dapat memahami masalah yang diteliti serta dianalisis sesuai dengan tujuan yang diinginkan.

3. Menarik Kesimpulan;

Menarik kesimpulan dengan cara pengembangkan sebuah paragraf lalu menarik sebuah gagasan utama dan simpulan umum berdasarkan kerjadian yang ada. Selain itu penarikan kesimpulan dapat dilakukan dengan cara pengembangan sebuah paragraf menggunkan sebab akibat . kesimpulan hanyalah sebuah sebagian 
dari pembahasan yang ada. Kesimpulan dibuat agar pembeca bisa memahami secara singkat dari pembahasan sebelumnya. Saat penelitian berlangsung kesimpulan juga diverifikasi terlebih dahulu.

Dalam Artikel ini menggunakan metode analisis data kualitatif. Metode analisis data kualitatif adalah pendekatan pengolahan secara mendalam data hasil pengamatan, wawancara, dan dari data angket yang telah kami buat. Sistematika atau urutan yang ada dalam penelitian memberikan pola berfikir secara sistematis, komplek dan mampu mengungkan gejala yang ada dimsyarakat secara sistematis. Penelitian kualitatif tidak dapat ditolak kebenarannya oleh masyarakat, karena penelitian ini dibuat sesuai keadaan nyata dilapangan.

\section{Instrumen Penelitian}

1. Studi kepustakaan

Studi kepustakaan ini dilakukan dengan cara membaca literatur-literatur yang berhubungan dengan permasalahan yang sedang diteliti dan dapat dijadikan sebagai landasan teoritis bagi pembahasan masalah.

2. Metode interview (wawancara)

Metode wawancara dilakukan dengan cara wawancara dengan pihak-pihak yang terkait dengan penelitian.

Definisi operasional variabel

Pajak Pertambahan Nilai (PPN) adalah pajak yang dapat dikenakan terhadap penyerahan atau impor barang kena pajak atau jasa kena pajak yang dilakukan oleh pengusaha kena pajak dan dapat dikenakan berkali-kali setiap ada Pajak Pertambahan Nilai (PPN) dan dikreditkan. Suandy (2003:59)

\section{Metode Analisis Data}

1) Melaksanakan perhitungan Pajak Pertambahan Nilai (PPN) menurut perusahaan dengan dibandingkan dengan perhitungan Pajak Pertambahan Nilai (PPN) menurut Undang-Undang Perpajakan tentang Pajak Pertambahan Nilai (PPN). 
2) Menganalisis dan menarik kesimpulan atas perhitungan perbandingan Pajak Pertambahan Nilai (PPN) menurut perusahaan dengan perhitungan Pajak Pertambahan Nilai (PPN) menurut Undang-Undang Perpajakan.

3) Menganalisis perhitungan laporan laba rugi perusahaan setelah diketahui perhitungan perbandingan Pajak Pertambahan Nilai (PPN) menurut perusahaan dengan perhitungan Pajak Pertambahan Nilai (PPN) menurut Undang-Undang Perpajakan. 


\section{HASIL PENELITIAN DAN PEMBAHASAN}

Pada bab ini berisi tentang pembahasan terhadap rumusan masalah yang telah disampaikan pada bab pendahuluan. Rumusan masalah yang dibahas meliputi penerapan akuntansi ppn serta penghitungan, penyetoran serta pelaporan Pajak Pertambahan Nilai (PPN) terutang ke Direktorat Jenderal Pajak /Kantor Pelayanan Pajak (KPP).

\section{Penerapan Akuntansi Pajak Pertambahan Nilai Pada Toko Kue Nak Mbarep}

Akuntansi Pajak Pertambahan Nilai pada Toko Kue Nak Mbarep meliputi pencatatan transaksi penjualan yang terkait dengan pajak keluaran dan pajak masukan. Akuntansi sendiri merupakan proses pencatatan, penggolongan, pengklasifikasian, peringkasan, pengikhtisaran dan penyajian dengan cara-cara tertentu terhadap transaksi keuangan (finansial) yang terjadi dalam perusahaan atau organisasi lainnya.

Tujuan dari akuntansi Pajak Pertambahan Nilai adalah memberikan informasi bagi perusahaan untuk dapat menghitung, membayar dan melaporkan pemenuhan kewajiban Pajak Pertambahan Nilai. Berdasarkan tujuan tersebut perusahaan telah melakukan kegiatan pencatatan atas setiap penjualan BKP/JKP yang berhubungan dengan pembayaran maupun pemungutan PPN. Namun untuk pencatatan atas pajak keluaran masih ada kelemahan karena kurang catat.

Seperti yang telah diuraikan sebelumnya bahwa ada beberapa transaksi pajak keluaran yang kurang catat. Hal ini kurang baik karena pelaporan PPN keluaran juga akan menjadi kekecilan. Hal ini dapat dikenakan sanksi perpajakan berupa kurang bayar dan denda. Ketentuan mengenai waktu penerbitan faktur terkait dengan pencatatan yang dilakukan terhadap pemungutan PPN, dan berhubungan dengan jumlah yang akan dibayar juga akan berpengaruh karena kurang catat PPN keluaran. 
2. Analisis Perhitungan, Penyetoran dan Pelaporan PPN pada Toko Kue Nak mbarep

Akuntansi Pajak Pertambahan Nilai terdiri dari 3 bagian yaitu perhitungan , penyetoran dan pelaporan. Hal ini berkaitan erat dengan laporan keungan yang akan disajikan. Adanya akuntansi Pajak Pertambahan Nilai diharapkan agar transaksi usaha, yang berhubungan dengan PPN berjalan sesuai dengan prosedur dan ketentuan peraturan perundang-undangan yang berlaku dan dapat menghasilkan informasi keuangan yang wajar, sesuai Standar Akuntansi Keuangan. Maka hal-hal penting yang perlu diperhalikan dalam akuntansi Pajak Pertambahan Nilai yaitu :

\subsection{Analisis penghitungan Pajak Pertambahan Nilai}

Analisis ini dilakukan untuk mengetahui perhitungan PPN pada Toko Kue Nak Mbarep. Secara umum, penghitungan jumlah PPN yang terutang ini bertujuan untuk mengetahui besarnya pajak yang terutang oleh Pengusaha Kena Pajak (PKP), yang harus di bayarkan ke KPP tempat pengusaha tersebut terdaftar atau sebagai PKP. Setelah besarnya PPN terutang di ketahui, maka kewajiban selanjutnya PKP tersebut adalah menyetorkan atau melunasi atau membayar utang pajaknya dan melaporkan penyetoran pajak tersebut. Cara menghitung PPN yang terutang adalah dengan mengalikan tarif PPN sebesar $10 \%$, atau $0 \%$ untuk ekspor barang, dengan Dasar Pengenaan Pajaknya (DPP). Atau dapat di rumuskan sebagai berikut

PPN yang terutang $=$ Tarif PPN $x$ DPP

Dengan rumus di atas DPP merupakan jumlah harga jual, penggantian, nilai impor, nilai ekspor, atau nilai lain yang ditetapkan oleh Menteri Keuangan sebagai dasar untuk menghitung pajak yang terutang. PPN yang terutang ini merupakan Pajak Keluaran yang dipungut oleh PKP dan bagi PKP pembeli merupakan Pajak Masukan. Sebagai Wajib Pajak Pertambahan Nilai, Toko Kue Nak Mbarep menghitung sendiri besarnya PPN yang terutang untuk tiap masa pajak. Berikut ini adalah uraian buku penjualan dan perhitungan PPN keluaran Toko Kue Nak Mbarep 
Pada Bulan November 2020.

Laporan Laba Rugi Toko Kue Nak Mbarep Kepatihan Pada Bulan November 2020

\section{Pendapatan usaha :}

I. PENDAPATAN BERSIH

1. Penjualan Rp. 40.000 .000

Dikurangi :

I. BIAYA USAHA

1. Biaya Pembelian

Jumlah Biaya Usaha

Laba usaha
Rp. 8.000 .000

Rp. 8.000 .000 -

Rp. 32.000 .000

II. BIAYA OPERASIONAL

1. Gaji Karyawan

2. Alat Tulis Kantor, Fotocopy

3. Biaya Transportasi

4. Biaya Listrik \& Air

5. Biaya lain-lain

Total Biaya Operasional

Laba Operasional
Rp. 4.000 .000

Rp. 500.000

Rp. 500.000

Rp. 600.000

Rp. $1.000 .000+$

Rp. 6.600 .000 -

Rp. 25.400 .000

III. PENDAPATAN \& BIAYA LAIN-LAIN

Pendapatan Lain-lain :

Jasa Giro

Rp. $1.000 .000+$

Total pendapatan

Rp. 26.400 .000

Biaya Lain-lain : 
Biaya Administrasi dan Provisi Bank

Laba sebelum pajak

Pajak Pertambahan Nilai

Pajak Penghasilan

Jumlah Pajak

Laba Bersih Setelah Pajak
Rp. 1.700 .000 -

Rp. 24.700 .000

Rp. 3.200 .000

Rp. $\quad 20.000+$

Rp. 3.220.000-

Rp. 21. 480.00

Pajak keluaran yang dapat dihitung adalah sebagai berikut :

Pendapatan

$10 \%$ X Rp. $40.000 .000=$

Total pajak keluaran

Pembelian bahan baku

Total pembelian bahan baku
Rp. 4.000 .000

Rp. 4.000 .000

Rp. 8.000.000

Rp. 8.000.000

Pajak masukan yang dapat dikreditkan adalah : $10 \% \times$ Rp. $8.000 .000=$

Rp. 800.000

Sehingga pajak pertambahan nilai adalah sebagai berikut :

Pajak keluaran

Rp. 4.000 .000

Pajak masukan

Rp. 800.000 -

PPN yang terutang

Rp. 3.200 .00 


\subsection{Analisis Penyetoran Pajak Pertambahan Nilai}

Setelah menghitung besarnya pajak yang terutang, kewajiban selanjutnya bagi wajib pajak adalah menyetor dan melaporkan pajaknya. Berdasarkan perhitungan tersebut dapat di simpulkan bahwa Toko Kue Nak Mbarep telah memenuhi kewajiban perpajakannya dengan baik. Untuk masa pajak Desember 2020, besarnya pajak yang di setorkan ke Kantor Pelayanan Pajak adalah Rp. 4.000.000 jumlah tersebut di setorkan ke KPP dengan menggunakan SPT Masa PPN pada tanggal 20 Desember 2020.

Selain telah menghitung sendiri besarnya Pajak Pertambahan Nilai yang terutang sesuai dengan peraturan yang berlaku, Toko Kue Nak Mbarep juga menyetorkan sendiri sejumlah pajak yang terutang ke Kantor Pelayanan Pajak dengan menggunakan formulir Surat Setoran Pajak (SSP) selambat-lambatnya tanggal 15 bulan berikutnya setelah masa pajak berakhir, untuk setiap masa pajak.

\subsection{Analisis Pelaporan Pajak Pertambahan Nilai}

Setelah itu, Toko Kue Nak Mbarep melaporkan pajaknya dengan menggunakan SPT Masa selambat-lambatnya tanggal 20 bulan berikutnya setelah masa pajak berakhir, untuk setiap masa pajak.

Dengan demikian dapat di simpulkan bahwa Toko Kue Nak Mbarep telah memenuhi kewajibannya sebagai wajib pajak PPN dengan baik. Toko Kue Nak Mbarep telah menghitung besarnya pajak yang terutang, menyetorkan pajak yang terutang ke KPP dengan menggunakan SSP serta telah melaporkan PPN dengan menggunakan SPT Masa dengan tepat waktu dan sesuai Undang-undang No 42 tahun 2009 tentang PPN dan PPnBM. 


\section{PENUTUP}

\section{Kesimpulan}

Dalam perhitungan Pajak Pertambahan Nilai(PPN) dapat digunakan metode tidak langsung yaitu pajak keluaran dikurangi pajak masukan hasil yang diperoleh adalah merupakan pajak yang harus disetor ke kas Negara. Dalam membuat atau mencatat Pajak Pertambahan Nilai(PPN) ini untuk pembuatan laporan diperlukan informasi yang jelas mengenai transaksi-transaksi yang akan digunakan. Transaksitransaksi itu berupa transaksi penjualan dan pembeliaan yang merupakan hal penting dalam mencari Pajak Pertambahan Nilai(PPN). Dalam perhitungan PPN harus mengalikan $10 \%$ dengan DPP.

Dari Analisis pada pembahasan diatas pada bulan November tahun 2020 laporan laba rugi diperolah dari Pajak Pertambahan Nilai(PPN) sejumlah Rp 3.200,00. Dengan adanya perhitungan kembali terhadap Pajak Pertambahan Nilai(PPN) pada Industri Kue Nak Mbarep dihapkan menjadi acuan dalam laporan PPN agar laporan tersebut jelas sesuai transaksi yang terjadi. PPN dapat diketahui bahwa besarnya PPN yang seharusnya menjadi beban perusahaan ini, sehingga hasilnya diadakan perhitungan kembali dan laba sebuah industry tersebut akan lebih tinggi dari keadaan sebelumnya, sebelum dikenakan PPN. Namun sebelum barang atau jasa itu sampai kepada konsumen, PPN telah dikenakan pada setiap rantai jalur produksi maupun jalur distribusi. Hal itu dikarenakan Pajak Pertambahan Nilai (PPN) yang menjadi beban perusahaan jumlahnya besar.

Setelah itu, Toko Kue Nak Mbarep melaporkan pajaknya dengan menggunakan SPT Masa selambat-lambatnya tanggal 20 bulan berikutnya setelah masa pajak berakhir, untuk setiap masa pajak. Dengan demikian dapat di simpulkan bahwa Toko Kue Nak Mbarep telah memenuhi kewajibannya sebagai wajib pajak PPN dengan baik. Toko Kue Nak Mbarep telah menghitung besarnya pajak yang terutang, menyetorkan pajak yang terutang ke KPP dengan menggunakan SSP serta telah melaporkan PPN dengan menggunakan SPT Masa dengan tepat waktu dan 
sesuai Undang-undang No 18 tahun 2000 tentang PPN dan PPBM

Saran

Berdasarkan uraian mengenai Perpajakan tentang Pajak Pertambahan Nilai(PPN) ini diharapkan dapat mengimplementasikan teori dan perhitungan yang ada didalam makalah ini. Perhitungan dibuat secara ringkas dan singkat agar mudah dipahami oleh peneliti atau pembaca selanjutnya. Dalam Pepajakan Di Indonesia ini sangat bepengaruh terhadap pendapatan atau Kas Negara. Hal itu dikarenakan, pajak merupakan salah satu indikator penting dalam pembangunanan negara Indonesia ini. Oleh karena itu dalam pengolahan pajak harus diolah dengan baik, jujur dan transparan. Apabila diolah dengan baik maka kita akan merasakan maanfaat yang besar dalam kehidupan bernegara ini. Selain itu harus adanya dorongan terhadap masyarakat untuk taat membayar pajak. Karena kalau wajib pajak taat membayar pajak pasti pembangunan akan merata dan pertumbuhan ekonomi menjadi pesat. Tetapi tidak dapat dipungkiri bahwa, masih banyak masyarakat yang takut akan membayar pajak. Alasannya, karena takut uangnya terkuras habis hanya untuk membayar pajak. Anggapan tersebut sangat tidak benar. Karena apabila wajib pajak membayar pajak dengan tepat waktu, dan uang dari pajak diolah dengan tepat maka akan menimbulkan efek positif untuk kesejahteraan masyarakat dan negara. Maka dari itu kita harus sebagai warga negara harus paham terlebih dahulu mengenai subjek pajak, objek pajak, serta tarif pajak yang sudah berlaku dilndonesia. Sehingga kita menjadi warga Indonesia yang taat pajak. 


\section{DAFTAR PUSTAKA}

Prabowo, Rachmad Gesah Mukti. 2019. "MEKANISME PPN Dan PPnBM." Mekanisme PPn Dan PPnBM.

Arikunto, Suharsimi. 2002. Prosedur Penelitian Suatu Pendekatan Praktek. Jakarta: Rineka Cipta.

Fitriandi. Primandita, Birowo. Tejo, Aryanto. Yuda. 2006. Komplikasi Undangundang Perpajakan Terlengkap. Edisi kedua. Jakarta: Salemba

Empat.

Helmy, Alfian. 2005. diktat Hukum Perpajakan.

Helmy, Alfian. 2005. diktat Perpajakan.

Hidayah, Nurul. dkk. 2008. Ilmu Pengetahuan Sosial. Lamongan: UD Rismah Cendekia.

Mardiasmo. 2003. Perpajakan. Edisi revisi tahun 2002. Yogyakarta: Andi.

Suandy, Erly. 2006. Perpajakan. Edisi kedua. Jakarta: Salemba Empat.

Suandy, Erly. 2003. Hukum Pajak. Jakarta: Salemba Empat.

Supardi. 2005. Metode Penelitian Ekonomi \& Bisnis. Yogyakrta: IKAPI

Urifa. Arwa (2009), Evaluasi Atas Perhitungan Pajak Pertambahan Nilai Pada

Perusahaan Rokok Roky Internasional Kalen Kedungpring Lamongan.

Skripsi UNISDA Lamongan, Tidak Dipublikasikan.

Waluyo. Ilyas, Wirawan (2002), Perpajakan Indonesia. Jakarta, Salemba Empat. 
Analisis Implementasi.Paj... Kepatihan 
Analisis Implementasi.Paj... Kepatihan 
Analisis Implementasi.Paj... Kepatihan 